\title{
Stefan A. Schmidt: Zugang zu Daten nach europäischem Kartellrecht
}

\author{
Mohr Siebeck, Tübingen 2020. pp. 629 (+XXII). \\ ISBN: 978-3-16-159580-6. €124.00
}

\section{Heiko Richter}

Accepted: 11 January 2021 / Published online: 16 February 2021

(C) The Author(s) 2021

Written in German, Stefan A. Schmidt's doctoral thesis "Zugang zu Daten nach europäischem Kartellrecht" ("Access to Data under European Competition Law") is a work that is worth reading. Stressing the importance of data for society and business in the age of Big Data and machine learning has become commonplace nowadays. The regulation of access to data is a challenge that has become equally relevant for both legal academia and politics, and the debate about the supremacy of technology giants has even reached the daily press on both sides of the Atlantic. Especially the far-reaching and long-lasting effects of data-related monopolies on competition bring competition law into focus, which - arguably - can be used to force dominant undertakings to grant other companies access to their data. And this is precisely where Schmidt's thesis comes in, as it examines how and under what circumstances EU competition law can mandate such access to data. This debate is embedded in and adds to the general discourses on "refusals to deal", "refusals to license" and "essential facilities", which have puzzled and excited competition law scholars from early on, not only because of their tempting complexity, but also because of their systemic significance: Mandating private undertakings to share their resources with others touches the heart of the market economy and private ordering. It poses the question how far the autonomy of private actors extends and when the use of market freedoms tips over into a restriction of competition, which in turn might justify intervening to ensure the undistorted competitive process. These questions have regained attention in the digital world in recent years, and it is a challenge to address them in the realm of data-driven markets.

This brings us to the conception and content of the monography: Schmidt examines how Art. 102 TFEU can ensure competition in data-dependent markets through providing data access. In particular, the question is whether and under what

\footnotetext{
H. Richter $(\bowtie)$

Dr. iur. (Humboldt University of Berlin), LL.M. (Columbia), Dipl.-Kfm. (Mannheim); Senior Research Fellow, Max Planck Institute for Innovation and Competition, Munich, Germany e-mail: heiko.richter@ip.mpg.de
} 
conditions the obligations under Art. 102 TFEU can force a dominant undertaking to share its data with third parties. Obviously, this requires building on and further developing the methodology of the European courts and the Commission regarding access to physical facilities and intangible facilities (especially those subject to intellectual property protection), aka refusal to deal/license cases. Also data can undoubtedly constitute a bottleneck input, and one can therefore - at least at first glance - easily draw on Art. 102 TFEU on the basis of a situation of comparable interest. However, the peculiarity lies in the striking differences between ordinary intangible protected positions and data. This concerns the particular functioning of data-driven markets, related market delineation problems and the absence of exclusive rights conferred by law.

So, to what extent does the author address this issue? First of all, it is important to know that he puts the focus solely on Art. 102 TFEU, in particular refusal-to-deal cases. Only his last chapter takes a side glance at the still ongoing reform of the German "Act against Restraints of Competition", , where data-related competition law has been conceptualized early on. Schmidt admits upfront that competition law is not a panacea with regard to access to data. Rather, he justifies his focus on EU competition law as it appears as the only current legal regime to enable crossindustry access to data.

The structure of the book appears clear and intuitive. While chapter 1 outlines the object of study and the research approach, Chapter 2 is devoted to the technical and economic characteristics of data and their treatment in law. The author describes the relationship between data and information, undertakes a comprehensive categorization of data according to various characteristics, elaborates the economic features of data (including, in particular, the "platform problem") and the peculiarities of the "data value chain". He concludes the chapter by examining the role of data in the legal system, the key finding being that the current law does not provide for comprehensive protection of individual data.

Chapter 3 identifies intellectual property rights as a reference point for the regulatory treatment of data and, to this end, clarifies the foundations of intellectual property law, which Schmidt appropriately considers as indispensable for applying competition law in this domain. One may regard Chapter 3 as a concise outline of the theoretical foundations of intellectual property. In substance, Schmidt elaborates on the central function of the incentive paradigm: Because both the intellectual property regime and competition law focus on promoting efficiency, it must be possible to avoid conflicts of regulatory goals by diligently balancing these two legal regimes.

Chapter 4 is dedicated to the concept of access rights under Art. 102 TFEU and analyzes the competition law assessment of the refusal of access to physical and intangible goods. Schmidt starts from the cardinal assumption that competition law and intellectual property law pursue the promotion of dynamic competition processes in complementary application - this view may appropriately be called

\footnotetext{
1 See BT-Drs. 19/23492.
} 
"mainstream" today. Against this background, he elaborates the access doctrine on the basis of the CJEU's case law and the decision practice of the EU Commission. ${ }^{2}$ His analysis is both detailed and concise - even scholars who are familiar with the issues will find several passages of this critical discussion worth reading, such as on the absolute denial of access to internally used resources (which is highly relevant if data is the subject of access). Ultimately, and with reference to the Bronner case, Schmidt regards the identified doctrinal approach as a structured balancing of interests. According to this, (1) the good to which access is sought must be indispensable for the provision of services on a downstream market, (2) the refusal must exclude all effective competition on the downstream market, and (3) the conduct of the facility owner must not be objectively justified. In the author's view, the CJEU's Huawei decision has led to a relaxation of these criteria in favor of greater flexibility when being applied to individual cases. For this reason, Schmidt rejects the "new product requirement" (as constituted in Magill and IMS Health) and calls for a full balancing of all efficiencies. Admittedly, this requires a complicated consideration in each individual case.

Chapter 5 applies the findings to access to data and finally puts together all the puzzle pieces. To this end, the structured balancing of interests as developed in Chapter 4 is modified to some extent, taking into account the peculiarities of data (inter alia specific economic features of data, the impact on markets by generating external effects, as well as the protection of informational self-determination or data protection). Schmidt distinguishes between data for complementary and for stand-alone services and discusses numerous examples in which access to data has already had competitive effects. The analysis reveals the difficulty in accurately delineating markets, in particular for hypothetical data markets when such data has not yet been traded, if no downstream market exists for the product, and if access to downstream data services exists in secondary markets. The author then extensively discusses market entry barriers, which he mainly identifies in the area of data collection. In doing so, he also takes a look at the role of data portability (the interface with Art. 20 GDPR in particular), which can potentially solve consumer lock-in regarding services of dominant undertakings. Finally, Schmidt argues for adequate compensation that at least covers the costs of the provisioning process.

Thus (and after his final remarks in Chapter 6, in which Schmidt takes a quick look at the German reforms and identifies access to personal data as a particularly pressing regulatory challenge), the reader is left with a thorough analysis and the

\footnotetext{
2 Access to physical goods, facilities, or services: CJEU, 6 March 1974, Case C-6/73 Commercial Solvents, ECLI:EU:C:1974:18; CJEU, 14 February 1978, Case C-27/76 United Brands, ECLI:EU:C:1978:22; CJEU, 3 October 1985, Case C-311/84 Telemarketing, ECLI:EU:C:1985:394; CJEU, 13 December 1991, Case C-18/88 GB-Inno-BM, ECLI:EU:C:1991:474; the port decisions of the EU Commission (COM Decision, 11 June 1992, Sealink /B\&I - Holyhead, IV/34.174; COM Decision, 21 December 1993, port of Rødby (Denmark), 94/119/EC; COM Decision, 16 May 1995, Irish Continental Group v. CCI Morlaix (Roscoff), IV/35.388); CJEU, 26 November 1998, Case C-7/97 Bronner, ECLI:EU:C:1998:569. Access to intangible goods: CJEU, 5 October 1988, Case C-238/87 Volvo, ECLI:EU:C:1988:477; CJEU, 6 April 1995, Case C-241/91 P Magill, ECLI:EU:C:1995:98; CJEU, 29 April 2004, Case C-418/01 IMS Health, ECLI:EU:C:2004:257; General Court EU, 17 September 2007, Case T-201/04 Microsoft, ECLI:EU:T:2007:289.
} 
overall conclusion that much - if not all - involving this issue highly depends on the individual case. In order to have more clarity, one is virtually longing for the first decisions of the Commission and the EU courts on data access pursuant to Art. 102 TFEU. The book illuminates the enormous range of cases and constellations that competition law covers (and could potentially cover). Yet, the work predominantly stays within the domain of the legal doctrine, as it neither addresses the political drivers that (can) influence the competition authorities' decisions nor discusses the wider context for the economic framework order, in which the further development of competition law and policies are embedded before the background of a "databased" society.

Another open (but certainly too extensive) question concerns the implications of Schimdt's findings for the intellectual property regime. Data is only fragmentarily or incidentally protected under the intellectual property regime, ${ }^{3}$ and this insight has set the course for his further analysis. The status of intellectual property protection has therefore become a yardstick for the competition law assessment, and Schmidt treats the current intellectual property regime itself as a "constant". However, the intellectual property regime is in flux - especially sui generis database protection is a central regime which is currently under regulatory scrutiny. ${ }^{4}$ Its interplay with competition law was already a decisive factor for the enactment of the Database Directive of 1996: The proposed inclusion of a compulsory licensing provision within the Directive was abandoned "last minute" because, among other things, the CJEU's Magill decision was handed down in 1995, thus during the legislative process, and was therefore held to withdraw the basis for such a compulsory licensing provision. ${ }^{5}$ What remained in the Database Directive is the merely declaratory reference to competition law in recital 47 . Who could have imagined back in those days what would follow in the subsequent 25 years with regard to Art. 102 TFEU and that so much legal uncertainty will pervade these significant questions to this day?

In addition, beyond the ex post regime of Art. 102 TFEU, EU competition and digital policies have recently entered a new age. In fact, some of the constellations addressed in this book are likely to be covered by an ex ante regulatory regime in the future. What the Commission has now proposed for a Digital Markets Act ${ }^{6}$ has been published more than half a year later than the author could consider for his work (his last sources are from May 2020). But in fact, the proposed DMA and the current German competition law reform open a new chapter for the competition law debate. Why special regulation is needed, and why the EU will most likely move away from solely relying on competition law follows several policy considerations - time pressure and legal certainty probably being the main reasons. Lengthy and

\footnotetext{
3 See on the recent discourse of how to further develop intellectual property law the WIPO consultation on Intellectual Property (IP) and Artificial Intelligence (AI), WIPO/IP/AI/2/GE/20/1 REV.

4 See $\operatorname{COM(2020)} 66$ final - A European strategy for data, p. 13; COM(2020) 760 final - Making the most of the EU's innovative potential: An intellectual property action plan to support the EU's recovery and resilience, p. 14.

5 See Gaster J-L (1999), Der Rechtsschutz von Datenbanken, Heymann (Köln), para. 570 ff.

6 See COM(2020) 842 final - Proposal for a Digital Markets Act.
} 
unpredictable competition law assessments combined with the enormous potential harm to competition when being too late have led many scholars in recent years to argue for complementary ex ante regulation. But from a more fundamental point of view, access cases are located at the intersection between competition law and regulation, due to their high intensity of intervention and far-reaching impact (especially when purely internally used data and hypothetical markets are affected).

All these points which have been raised are not criticisms, but rather interventions and affirmations of how central competition law is for the accessto-data debate. In this respect, Schmidt's work proves to be well suited and adaptable for research in other fields of data-related law. Rather than the positions taken in detail or the scientific novelty of the topic as such (the fact that legislators have only recently initiated reforms here should not make us forget that Inge Graef published a monography on "Data as essential facility" in $2016^{7}$ ), it is the accuracy and comprehensiveness of analysis, which fills a research gap here. Overall, the book appears obviously useful for persons who are particularly concerned with access to data from a competition law point of view. However, the work also provides a well-researched compendium on the basic legal doctrine and economics of access to essential facilities under Art. 102 TFEU and can thus enrich bookshelves as a reference work beyond the world of data. Finally, it is pleasing that Schmidt writes in a clear manner and that the link back to the fundamental assumptions makes the derivation of the author's conclusions appear more transparent. Not least for this reason, Schmidt's work can also be recommended to researchers who deal with data law in general but who have not yet come into contact with competition law and who would like to find their way here. What remains is a caveat - the potential reader should be willing to invest two assets: time (with almost 600 pages of text, this book provides everything but a crash course) and money (at €124.00, be it hardcover or digital, most people will solely rely on their research institutions to get access to it).

Funding Open Access funding enabled and organized by Projekt DEAL.

Open Access This article is licensed under a Creative Commons Attribution 4.0 International License, which permits use, sharing, adaptation, distribution and reproduction in any medium or format, as long as you give appropriate credit to the original author(s) and the source, provide a link to the Creative Commons licence, and indicate if changes were made. The images or other third party material in this article are included in the article's Creative Commons licence, unless indicated otherwise in a credit line to the material. If material is not included in the article's Creative Commons licence and your intended use is not permitted by statutory regulation or exceeds the permitted use, you will need to obtain permission directly from the copyright holder. To view a copy of this licence, visit http:// creativecommons.org/licenses/by/4.0/.

Publisher's Note Springer Nature remains neutral with regard to jurisdictional claims in published maps and institutional affiliations.

\footnotetext{
7 See Graef I (2016) "EU competition law, data protection and online platforms, data as essential facility", Wolters Kluwer (Alphen aan den Rijn), also available as open access at https://core.ac.uk/ download/pdf/34662689.pdf; for the German law, Grothe N (2019) Datenmacht in der kartellrechtlichen Missbrauchskontrolle, Nomos (Baden-Baden).
} 